ISSN : 2087-2461

PENANGGUNG JAWAB

Dekan FIKOM

Evie Sofiati MI, M.I.Kom

Sekretaris Dekan

Dian Marhaeni K, M.Si

Ketua Penyunting

Made Dwi Adnjani, M.Si

Sekretaris

Mubarok, M.Si

Bendahara

Parwati, SH

Dewan Penyunting

Trimanah, M.Si

Edi Ismoyo, M.Si

Suharyoso, S.Sos

Seksi Usaha

Endang Winarsih, S.Sos

Sirkulasi dan Distribusi

Novi, S.Sos

Alamat Redaksi

Fakultas Ilmu Komunikasi

Universitas Islam

Sultan Agung Semarang

Jl. Raya Kaligawe Km. 4

Po. Box 1054/SM

Semarang 50112

Telp. (024) 6583584

ext. $448 / 449$

Fax. (024) 6582455

email : jurnalfikom@yahoo.com
Pergeseran Makna Motif Batik Yogyakarta - Surakarta

Doddy Wihardi

Email:made_doddywihardi@yahoo.com

Riyodina G.Pratikto

Email:dinapratikto@yahoo.com

Shinta Kristanty

Email:shintasoultan@yahoo.com

Diskursus Cyberbullying Florence Sihombing

(Analisis Wacana Kritis Teun A. Van Dijk

Tentang Florence Sihombing di Dunia Maya)

Syntia Balina Dewi

syntiabalinadewi@gmail.com

Syarif Maulana

syarafmaulini@gmail.com

Kajian Interaksi Simbolik Pola Komunikasi

Etnis Arab dan Etnis Sunda Dalam Perkawinan Mut'ah

di Kecamatan Pacet Kabupaten Cianjur

Yessi Sri Utami

yessikhansa@gmail.com

Tabloidisasi Pemberitaan Mengenai Pemilu Presiden 2014

Pada Program Berita "Headline News" Metro TV

Urip Mulyadi

oeripmulia@gmail.com

Relevansi Teori Agenda Setting

Dalam Dunia Tanpa Batas

Kharisma Nasionalita

k_nasionalita@yahoo.co.id

"Children Go Online" di Indonesia, Apa dan Bagaimana? Nurist Surayya

nurist.surayya@undip.ac.id 


\title{
PERGESERAN MAKNA MOTIF BATIK YOGYAKARTA - SURAKARTA
}

\author{
Oleh : \\ Doddy Wihardi \\ Dosen Fakultas Ilmu Komunikasi Universitas Budi Luhur, Jakarta \\ Email: made_doddywihardi@yahoo.com \\ Riyodina G.Pratikto \\ Dosen Fakultas Ilmu Komunikasi Universitas Budi Luhur, Jakarta \\ Email: dinapratikto@yahoo.com \\ Shinta Kristanty \\ Dosen Fakultas Ilmu Komunikasi Universitas Budi Luhur, Jakarta \\ Email: shintasoultan@yahoo.com
}

\begin{abstract}
Recognition the world to batik as the world cultural heritage belonging to Indonesia by UNESCO increase popularity batik. But the increase was not in balance to understanding of meaning philosophical in any motive batik, for example the use of batik by the community not in accordance with the designation on motive that is. Research aims to understand shift the meaning of elements batik Yogyakarta-Surakarta. Research questions submitted is how shift meaning on motive batik Yogyakarta-Surakarta? Research methodology used is analysis logician Roland Barthes. An object used in this research was batik Yogyakarta-Surakarta. Data obtained from observation to a batik Yogyakarta-Surakarta traditional and contemporary, book, journal, interview as well as from sources online. Output from the study will make a journal and a recommendations for institutions associated with the development of batik like: the government, Batik entrepreneurs and consumers.
\end{abstract}

Key words: Batik, meaning, motif

\section{Pendahuluan.}

Batik merupakan seni melukis corak tertentu di atas kain dengan menggunakan berbagai motif, maupun warna. Pada setiap motif batik tersebut terdapat berbagai makna yang tersirat di dalamnya. Dalam kamus besar bahasa Indonesia, batik dijelaskan sebagai kain bergambar yang dibuat secara khusus dengan menuliskan atau menerakan malam (lilin) pada kain, kemudian pengolahannya diproses dengan cara tertentu, atau biasa dikenal dengan kain batik (Aris Wulandari, 2011:2). Seni batik dapat dikaitkan pula dengan ilmu komunikasi, khususnya komunikasi visual.

Komunikasi visual merupakan ilmu yang mempelajari tentang pesan, yang disampaikan secara visual, dengan menggunakan unsur-unsur visual, yaitu melalui bentuk, pola, dan warna serta tata letak yang dikomposisikan sedemikian rupa dengan mempertimbangkan unsur estetika, sehingga tercapai komposisi harmonis dan menarik.

Batik pada awalnya merupakan seni gambar atau lukis di atas kain untuk pakaian raja-raja. Hal ini menjadi salah suatu kebudayaan keluarga raja-raja di Indonesia jaman dahulu. Pembuatan batik semula dikerjakan hanya terbatas dalam lingkungan keraton saja dan hasilnya digunakan untuk pakaian raja, keluarga kerajaan serta para pengikutnya. Oleh karena banyak dari pengikut raja tinggal di luar keraton, maka kesenian batik ini dibawa oleh mereka ke luar lingkungan keraton dan dikerjakan di tempat mereka masing-masing (www.solobatik. althost.net, 2012).

Beragam budaya yang terdapat di Indonesia menyebabkan munculnya beragam 
jenis batik yang mencerminkan karakteristik setiap daerah. Misalnya, Batik YogyakartaSurakarta, merupakan salah satu dari sekian banyak motif yang terdapat di Indonesia. Batik Yogyakarta-Surakarta adalah sebuah warisan kesenian budaya orang Indonesia, khususnya daerah Jawa yang dikuasai orang Jawa secara turun-temurun. Batik Jawa mempunyai motif yang berbeda-beda antar daerah yang satu dengan daerah lainnya. Perbedaan motif ini terjadi karena motif-motif tersebut memiliki makna yang diperoleh dari para leluhur mereka. Selain di Yogyakarta, Batik Jawa juga berkembang di daerah Surakarta atau disebut dengan Batik Solo. Sejak ditetapkannya batik sebagai Warisan Kemanusiaan untuk Budaya Lisan dan Nonbendawi (Masterpieces of the Oral and Intangible Heritage of Humanity) oleh United Nations Educational, Scientific and Cultural Organization (UNESCO) pada 2 Oktober 2009, batik semakin digemari oleh masyarakat Indonesia maupun masyarakat asing. Berbagai kalangan di masyarakat telah menggunakan batik dalam keseharian maupun untuk acara-acara khusus (Ishwara dkk, 2011:19).

Akan tetapi meningkatnya popularitas batik di masyarakat luas tidak disertai dengan tingkat pemahaman yang memadai tentang filosofi yang terkandung di dalam setiap motif batik. Hal tersebut disebabkan oleh minimnya kepedulian masyarakat terhadap maknamakna yang terkandung di dalam suatu produk, termasuk batik. Kondisi tersebut semakin dipicu oleh kuatnya budaya kapitalisme yang berkembang luas di Indonesia.

Kondisi demikian memunculkan kecenderungan akan adanya pergeseran makna yang terkandung di dalam setiap motif batik, khususnya motif Batik YogyakartaSurakarta. Perkembangan batik saat ini telah mengakibatkan motif-motif batik yang dihasilkan disesuaikan dengan kebutuhan pasar, sehingga timbul kekhawatiran akan pudarnya filosofi atau nilai-nilai asli dan luhur dari motif batik tersebut.

Saat ini terdapat sekitar 4.5 juta bisnis batik di Indonesia, dan empat juta di antaranya terdapat hampir di seluruh Pulau
Jawa. Sementara sisanya terdapat di berbagai tempat di luar Pulau Jawa. Para pebisnis batik tersebut mulai mengarah kepada produksi yang bersifat massal dengan menggunakan pendekatan teknologi kekinian. Sehingga metoda asli dalam proses membatik, atas dasar komersialisasi mulai ditinggalkan. Untuk itu, penelitian ini akan terfokus pada adanya pergeseran makna pada motif batik Yogyakarta-Surakarta yang terjadi di masyarakat. Penelitian ini memiliki artipenting karena pesatnya perkembangan produksi batik yang berorientasi pada bisnis belaka, akan berdampak pada pudarnya filosofis serta nilai-nilai asli yang terkandung dalam proses membatik itu sendiri. Oleh karena itu penelitian ini akan banyak mengulas seputar filosofi yang terkandung di dalam motif batik Yogyakarta-Surakarta, perkembangan industri batik di masyarakat, kemunculan motif-motif batik Yogyakarta-Surakarta kontemporer serta dampak dari komersialisasi batik terhadap nilai-nilai asli dari batik. Sehingga rumusan masalahnya adalah

1. Bagaimana proses terjadinya pergeseran makna pada motif batik YogyakartaSurakarta?

2. Bagaimana dampak yang dimunculkan dari pergeseran makna pada motif batik Yogyakarta-Surakarta?

\section{Kerangka Teori \\ Komunikasi visual}

Komunikasi

visual adalah

"komunikasi menggunakan bahasa visual, di mana unsur dasar bahasa visual yang menjadi kekuatan utama dalam penyampaian pesan adalah segala sesuatu yang dapat dilihat dan dan dapat dipakai untuk menyampaikan arti, makna, atau pesan." (Kusriyanto, 2007:10

\section{Unsur - unsur Visual}

Menurut Adi Kusrianto, Untuk mewujudkan suatu tampilan visual, ada beberapa unsur yang diperlukan, yaitu: 1. Titik: Titik adalah salah satu unsur visual yang wujudnya relatif kecil, dimana dimensi memanjang dan melebarnya dianggap tidak berarti. Titik cenderung 
ditampilkan dalam bentuk kelompok, dengan variasi jumlah,susunan, dan kepadatan tertentu.

2. Garis: Garis dianggap sebagai unsur visual yang banyak berpengaruh terhadap pembentukan suatu objek sehingga garis, selain dikenal sebagai goresan atau coretan, juga menjadi batas limit suatu bidang atau warna. Ciri khas garis adalah terdapatnya arah serta dimensi memanjang. Garis dapat tampil dalam bentuk lurus, lengkung, gelombang, zigzag, dan lainnya. Kualitas garis ditentukan oleh tiga hal, yaitu orang yang membuatnya, alat yang digunakan serta bidang dasar tempat garis digoreskan.

3. Bidang: Bidang merupakan unsur visual yang berdimensi panjang dan lebar. Ditinjau dari bentuknya, bidang bisa dikelompokkan menjadi dua, yaitu bidang geometri/beraturan dan bidang non geometri alias tidak beraturan.

4. Ruang: Ruang dapat dihadirkan dengan adanya bidang, pembagian bidang atau jarak antar objek berunsur titik, garis, bidang, dan warna. Ruang lebih mengarah pada perwujudan tiga dimensi sehingga ruang dapat dibagi dua, yaitu ruang nyata dan semu. Keberadaan ruang sebagai salah satu unsur visual sebenarnya tidak dapat diraba tetapi dapat dimengerti.

5. Warna: Warna sebagai unsur visual yang berkaitan dengan bahan yang mendukung keberadaannya ditentukan oleh jenis pigmennya. Kesan yang diterima oleh mata lebih ditentukan oleh cahaya. Permasalahan mendasar dari warna di antaranya adalah Hue ( spektrum warna), Saturation (nilai kepekatan), dan lightness (nilai cahaya dari gelap ke terang).

6. Tekstur: Tekstur adalah nilai raba dari suatu permukaan, secara fisik tekstur dibagi menjadi tekstur kasar dan halus, dengan kesan pantul mengkilat dan kusam. Ditinjau dari efek tampilannya, tekstur digolongkan menjadi tekstur nyata dan tekstur semu

7. Simbol: Simbol atau lambang adalah semacam tanda, lukisan, perkataan, lencana, dan sebagainya yang menyatakan suatu hal, atau mengandung maksud tertentu yang bersifat konvensional, yaitu berdasarkan kesepakatan masyarakat. (Kusriyanto, 2007 : 30).

\section{Batik}

Menurut Robyn Maxwell dalam Textile of South East Asia: Tradition, Trade and Tranformation, batik tulis yang dibuat dengan canting dan malam baru berkembang pada abad ke-17. Sebelum canting ditemukan, pembubuhan perintang warna dilakukan dengan alat lain seperti tangkai bambu (Ishwara dkk, 2011:23-24).

\section{Motif batik}

Motif Batik adalah "suatu dasar atau pokok dari suatu pola gambar yang merupakan pangkal atau pusat suatu rancangan gambar, sehingga makna dari tanda, simbol atau lambang dibalik motif tersebut dapat diungkap". (Wulandari, 2011:113).

Motif batik terdiri dari dua bagian, yaitu ornamen motif batik dan isen motif batik. Penggolongan motif batik:

1. Motif geometris, yakni motif-motif batik yang ornamen-ornamennya merupakan susunan geometris. Ciri ragam hias geometris ini adalah motif tersebut mudah dibagi-bagi menjadi bagian-bagian yang disebut satu "raport". Golongan geometris ini pada dasarnya dapat dibedakan atas dua macam, yaitu: (a). Raportnya berbentuk seperti ilmu ukur biasa, seperti bentukbentuk segi empat, segi empat panjang atau lingkaran. Motif batik yang memiliki raport segi empat adalah golongan Banji, Ceplok, Ganggang dan Kawung. (b). Raportnya tersusun dalam garis miring, sehingga raportnya berbentuk semacam belah ketupat. Contoh motif ini adalah golongan Parang dan Udan liris.

2. Motif non-geometris, yakni motif-motif batik yang tidak geometris. Termasuk dalam motif ini adalah Semen, Buketan dan Terang bulan. Motif-motif golongan non-geometris tersusun dari ornamenornamen tumbuhan, meru, pohon hayat, candi, binatang, burung, garuda, ular 
(naga) dalam susunan tidak teratur menurut bidang geometris meskipun dalam bidang luas akan terjadi berulang kembali susunan motif tersebut. (Wulandari, 2011:113).

\section{Pergeseran Nilai}

Perkembangan teknologi yang pesat menyebabkan terjadinya perubahan sosial di dalam masyarakat. Masyarakat dituntut untuk menyesuaikan dirinya dengan keadaaan aktual dunianya sehingga harus melakukan berbagai perubahan, baik dalam pola pikir, sikap, maupun nilai-nilai yang dianutnya. Hal ini menyebabkan terjadinya perkembangan pranata dan pergeseran nilai-nilai. Menurut Horton dan Hunt, "Nilai adalah gagasan mengenai apakah suatu pengalaman itu berarti atau tidak berarti. Nilai pada hakikatnya mengarahkan perilaku dan pertimbangan seseorang, tetapi ia tidak menghakimi apakah sebuah perilaku tertentu itu salah atau benar" (Narwoko \& Suryanto, 2004:55).

\section{Makna}

Blumer (1969) menjelaskan bahwa terdapat tiga cara untuk menjelaskan asal sebuah makna. Satu pendekatan mengatakan bahwa makna adalah sesuatu yang bersifat intrinsik dari suatu benda. Pendekatan kedua terhadap asal-usul makna melihat makna itu "dibawa kepada benda oleh seseorang bagi siapa benda itu bermakna" (Blumer, 1969, hal. 4). Makna adalah "produk sosial" atau "ciptaan yang dibentuk dalam dan melalui pendefinisian aktivitas manusia ketika mereka berinteraksi" (Blummer, 1969, hal. 5) (West \& Turner, 2008:100).

\section{Semiotika}

Semiotika adalah "studi mengenai tanda (signs) dan simbol yang merupakan tradisi penting dalam pemikiran tradisi komunikasi. Pembahasan semiotika mencakup mengenai bagaimana tanda mewakili objek, ide, situasi, keadaan, perasaan, dan sebagainya yang berada di luar diri. Studi mengenai tanda tidak saja memberikan jalan atau cara dalam mempelajari komunikasi, tetapi juga memiliki efek besar pada hampir setiap aspek (perspektif) yang digunakan dalam teori komunikas.”i (Morissan, 2010 : 173).

\section{Semiotika Roland Barthes}

Barthes menyatakan ada dua macam sistem pemaknaan: "denotasi dan konotasi. Denotasi merupakan tingkat makna yang deskriptif dan literal yang dipahami oleh hampir semua anggota suatu kebudayaan. Pada tingkat kedua, yakni konotasi, makna tercipta dengan cara menghubungkan penanda-penanda dengan aspek kebudayaan yang lebih luas: keyakinan-keyakinan, sikap, kerangka kerja dan ideologi-ideologi suatu formasi sosial tertentu". (Barker, 2000:93). Mitos adalah produk kelas sosial yang sudah memiliki dominasi. Mitos adalah suatu wahana dimana ideologi berwujud (Sobur, 2006: 127128). Ciri-ciri mitos, yaitu:

1. Distorsif, hubungan antara form dan concept bersifat distorsif dan deformatif. Concept mendistorsi form sehingga makna pada sistem tingkat pertama bukan lagi merupakan makna yang menunjuk pada fakta yang sebenarnya.

2. Intensional, mitos tidak ada begitu saja. Mitos sengaja diciptakan, dikonstruksikan oleh budaya masyarakatnya dengan maksud tertentu.

3. Statement of fact, mitos menaturalisasikan pesan sehingga kita menerimanya sebagai sebuah kebenaran yang tidak perlu diperdebatkan lagi. Sesuatu yang terletak secara alami dalam nalar awam.

4. Motivasional, menurut Barthes, bentuk mitos mengandung motivasi. Mitos diciptakan dengan melakukan seleksi terhadap berbagai kemungkinan konsep yang akan digunakan berdasarkan sistem semiotik tingkat pertamanya.

\section{Perkembangan Batik dulu dan sekarang}

Pendapat Anne Richter dalam Sudarso yang mengemukakan bahwa pada zaman modern ini batik tidak hanya dipakai oleh para keluarga istana dan bagsawan, akan tetapi batik berkembang dan banyak diciptakan 
untuk diterapkan sebagai kemeja lengan panjang, rok, alas meja, serbet makan, bahkan juga gorden (Soedarso, 2006:61)

\section{Metode Penelitian}

Metode penelitian yang digunakan dalam penelitian ini, ialah metode analisis semiotika atau semiological analysis dari Roland Barthes

(Sudjiman, 1993: 46).

\section{Gambar 1. Metode Roland Barthes}

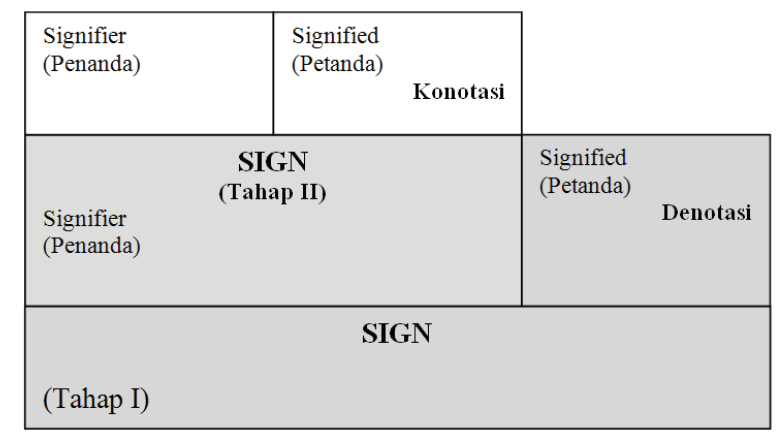

\section{Hasil Penelitian}

\section{Ciri Khas Batik Yogyakarta}

Batik Yogyakarta memiliki ciri khas, yaitu banyak bidang putih bersih dan motif geometrisnya dibuat besar-besar. Jauh lebih besar dibandingkan motif geometris di Surakarta yang relatif lebih kecil. Beberapa contoh motif batik Keraton Yogyakarta yang terkenal antara lain Parang Barong, Parang Rusak, Sido Asih, Truntum, Ceplok Kasatrian, Ceplok Belah Kedaton, Kawung, Tambal Nitik, Ceplok Naga Raja, Parang Kesit Tumarutum, dan lain-lain (Data diolah dari hasil wawancara).

Berikut ini ciri-ciri khusus batik Yogyakarta (Data diolah dari hasil wawancara) :

1. Berlatar belakang putih, hitam, coklat dan abu-abu.

2. Tidak terpengaruh dengan kolonial.

3. Motif Parang Rusak Barong hanya boleh digunakan oleh Sri Sultan Hamengkubuwono, dan digunakan untuk menerima tamu utusan dari berbagai negara atau untuk upacara perkawinan.
4. MotifCeplok Kesatrian memiliki makna filosofis menerima kritikan dari segala arah. Motif batik ini diperuntukkan untuk Sultan dan kerabatnya.

5. Motif Truntum digunakan untuk akad nikah.

6. Motif Sido Asih digunakan untuk resepsi.

7. Di Yogyakarta, Slobok berbentuk polos. Penggunaannya sebagai ikat pinggang. Slobok yang digunakan oleh Sri Sultan berbahan dengan kualitas terbaik.

8. Untuk penggunaan kain batik di Yogyakarta, posisi lereng dari kiri atas miring ke kanan bawah dengan posisi putihnya di luar. Motifnya lebih besar dan warna putihnya lebih putih ketimbang batik Surakarta.

\section{Ciri Khas Batik Surakarta}

Batik Kasunanan Surakarta diciptakan setelah tahun 1755, yaitu sejak masa pemerintahan Sunan Pakubuwono III. Batik Keraton Surakarta Hadiningrat penuh dengan isen halus. Warna batik Surakarta lembut, dari biru sampai kehitaman, krem, dan coklat kemerahan. Motif batik Surakarta yang terkenal antara lain Parang Barong, Parang Curiga, Parang Sarpa, Ceplok Burba, Candi Luhur, Srikaton, Bondhet, dan lain-lain. Berikut ciri-ciri batik Surakarta :

1. Penggunaan batik dengan lereng dari kanan atas miring ke kiri bawah, dengan pinggiran disembunyikan.

2. Batik Surakarta cenderung berlatar belakang kuning.

3. Menggunakan renda emas (gemerlap) sejak masa Pakubuwono III.

4. Tidak bisa dilepaskan dari pengaruh kolonial.

5. Slobok lebih digunakan sebagai kain yang bermotif. 


\section{Pergeseran Makna Motif pada Batik Yogyakarta Berdasarkan Analisis Semiotika Roland Barthes}

Gambar 4.1.

Analisis Tataran Pertama Motif Parang Rusak Barong

\begin{tabular}{|l|l|l|}
\hline \multicolumn{1}{|c|}{ Penanda } & \multicolumn{1}{c|}{ Pertanda } \\
\hline $\begin{array}{l}\text { Motif batik } \\
\text { dengan pola } \\
\text { geometris } \\
\text { dengan bentuk } \\
\text { belah ketupat. } \\
\text { Keseluruhan } \\
\text { di metaforakan } \\
\text { sebagai ombak di } \\
\text { lautan. } \\
\text { media kain } \\
\text { menampakkan } \\
\text { pola batik } \\
\text { bergaris miring } \\
\text { tegas, empat } \\
\text { puluh lima } \\
\text { derajat. }\end{array}$ & $\begin{array}{l}\text { Melambangkan } \\
\text { bahwa seorang } \\
\text { pemimpin } \\
\text { harus mampu } \\
\text { menghadapi } \\
\text { berbagai ujian } \\
\text { seperti ombak } \\
\text { yang menerpa } \\
\text { tebing. }\end{array}$ \\
\hline
\end{tabular}

Gambar 4.2.

Analisis Tataran Kedua Motif Parang Rusak Barong

\begin{tabular}{|c|c|}
\hline Penanda & Pertanda \\
\hline $\begin{array}{l}\text { Motif batik dengan } \\
\text { pola geometris } \\
\text { dengan bentuk } \\
\text { belah ketupat. } \\
\text { Keseluruhan bentuk } \\
\text { pada media kain } \\
\text { me n a m p a k a n } \\
\text { pola batik bergaris } \\
\text { miring tegas, empat } \\
\text { puluh lima derajat. }\end{array}$ & $\begin{array}{l}\text { Bentuk ombak laut yang susul- } \\
\text { menyusul menerpa tebing tempat } \\
\text { burung bertengger, mengandung } \\
\text { arti bahwa tidak ada sesuatupun } \\
\text { yang serba mulus. } \\
\text { Semua pasti mengalami gangguan, } \\
\text { cobaan atau ujian. Bila dihadapi } \\
\text { dengan bijak, akan mendatangkan } \\
\text { ketegaran. Semua keberhasilan } \\
\text { harus melalui pengorbanan lahir } \\
\text { dan batin. Motif Parang Rusak } \\
\text { Barong diciptakan oleh Sultan } \\
\text { Agung Hanyakrakusuma sebagai } \\
\text { ekspresi dari pengalamannya } \\
\text { selama menjadi raja dengan segala } \\
\text { tugas kewajibannya dan kesadaran } \\
\text { sebagai seorang manusia yang kecil } \\
\text { di hadapan Sang Maha Pencipta. } \\
\text { Melambangkan sikap rendah hati, } \\
\text { bijaksana dan bertanggung jawab } \\
\text { sebagai pemimpin. }\end{array}$ \\
\hline
\end{tabular}

Gambar 4.4.

Analisis Tataran Pertama

Logo Klub Sepak Bola Pada Motif Parang Rusak Barong

\begin{tabular}{|c|c|c|}
\hline Tanda & Penanda & $\begin{array}{c}\text { Makna } \\
\text { Konotasi }\end{array}$ \\
\hline & $\begin{array}{l}\text { Warna merah } \\
\text { dalam motif } \\
\text { parang rusak } \\
\text { barong } \\
\text { Logo salah } \\
\text { satu klub } \\
\text { sepakbola di } \\
\text { Italia, yakni } \\
\text { AC Milan. }\end{array}$ & $\begin{array}{l}\text { Warna merah } \\
\text { merepresentasikan } \\
\text { klub sepakbola } \\
\text { yang menjadi obyek } \\
\text { dalam batik tersebut } \\
\text { yaitu klub sepakbola } \\
\text {.(AC Milan (Italia } \\
\text { Logo AC Milan } \\
\text { menjadi salah } \\
\text { satu ornamentasi } \\
\text { pada produk } \\
\text { batik ini. Selain } \\
\text { itu, logo tersebut } \\
\text { melambangkan } \\
\text { fanatisme pendukung } \\
\text { klub tersebut }\end{array}$ \\
\hline
\end{tabular}

Gambar 4.2.

Analisis Tataran Kedua

Logo Klub Sepak Bola Pada Motif Parang Rusak Barong

\begin{tabular}{|c|c|}
\hline Penanda & Pertanda \\
\hline $\begin{array}{l}\text { Warna merah dalam } \\
\text { motif parang rusak } \\
\text { barong } \\
\text { Logo salah satu klub } \\
\text { sepakbola di Italia, } \\
\text { yakni AC Milan. }\end{array}$ & $\begin{array}{l}\text { Warna merah dan logo klub } \\
\text { sepak bola AC Milan pada } \\
\text { motif batik parang rusak barong } \\
\text { merepresentasikan ketangguhan } \\
\text { klub tersebut. } \\
\text { AC Milan merupakan salah } \\
\text { satu klub sepak bola terbesar di } \\
\text { Italia. Pretasi yang telah dicapai } \\
\text { oleh klub ini adalah di level } \\
\text { Eropa dan dunia. } \\
\text { Logo klub AC Milan didominasi } \\
\text { oleh warna merah, hitam dan } \\
\text { putih. }\end{array}$ \\
\hline
\end{tabular}


Pergeseran Makna Motif pada Batik Surakarta Berdasarkan Analisis Semiotika Roland Barthes

Gambar 4.3.

Analisis Tataran Kedua Motif Truntum Tradisional

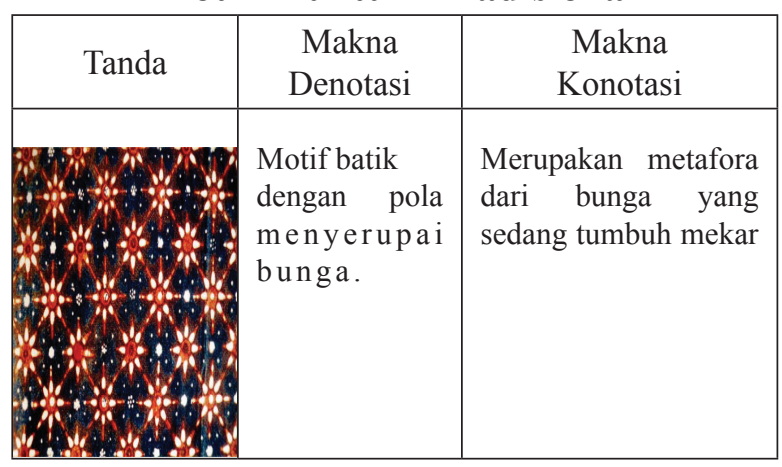

Gambar 4.3.

Analisis Tataran Kedua Motif Truntum Tradisional

\begin{tabular}{|l|l|}
\hline \multicolumn{1}{|c|}{ Penanda } & \multicolumn{1}{|c|}{ Pertanda } \\
\hline $\begin{array}{l}\text { Motif batik dengan } \\
\text { pola menyerupai }\end{array}$ & $\begin{array}{l}\text { Truntum melambangkan cinta } \\
\text { yang bersemi kembali sesuai dalam } \\
\text { bunga. Merupakan } \\
\text { metafora dari bunga } \\
\text { pemakaiannya, yakni dikenakan } \\
\text { yang sedang tumbuh } \\
\text { mekar }\end{array}$ \\
& upacara perkawinan. Motif \\
ini melambangkan orang tua \\
yang menuntun anaknya dalam \\
upacara pernikahan sebagai pintu \\
menjalankan kehidupan baru \\
yaitu kehidupan rumah tangga \\
yang sarat godaan. Diharapkan \\
melalui motif ini akan menjadikan \\
kehidupan pernikahan menjadi \\
langgeng serta diwarnai kasih \\
.sayang yang selalu bersemi
\end{tabular}

Gambar 4.4.

Analisis Tataran Pertama Logo Klub Sepak Bola Pada Motif Truntum

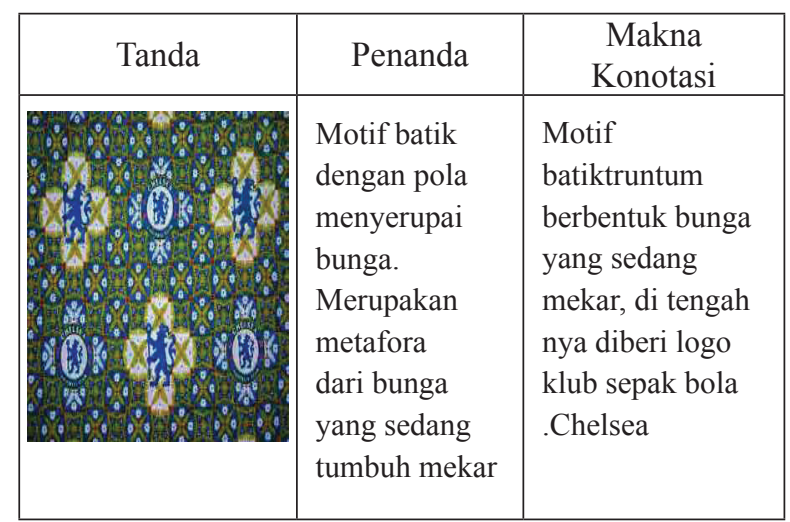

Gambar 4.3.

Analisis Tataran Kedua

Logo Klub Sepak Bola Pada Motif Truntum

\begin{tabular}{|c|c|}
\hline Penanda & Pertanda \\
\hline $\begin{array}{l}\text { Motif batik dengan } \\
\text { pola menyerupai } \\
\text { bunga. Merupakan } \\
\text { metafora dari bunga } \\
\text { yang sedang tumbuh } \\
\text { mekar }\end{array}$ & $\begin{array}{l}\text { Truntum melambangkan } \\
\text { cinta yang bersemi kembali } \\
\text { sesuai dalam pemakaiannya, } \\
\text { yakni dikenakan oleh orang } \\
\text { tua mempelai dalam upacara } \\
\text { perkawinan, telah mengalami } \\
\text { pergeseran ketika motif truntum } \\
\text { yang identik dengan bunga yang } \\
\text { sedang mekar, digsntikan oleh } \\
\text { logo klub sepak bola Chelsea }\end{array}$ \\
\hline
\end{tabular}

\section{Pembahasan}

Walaupun batik banyak digunakan di kalangan masyrakat, tetapi pesan-pesan yang terkandung dalam karya seni batik terkait dengan kehidupan tidak lagi banyak ditonjolkan. Hal itu tidak dapat dilepaskan dari proses pembatikan yang telah meninggalkan metode tradisional. Pembatikan cap atau printing secara motif lebih seragam karena berpatokan pada hasil yang memassal, sehingga mengaburkan kaidah-kaidah yang terkandung di dalam motif-motif tersebut.

Dalam perjalanannya saat ini, di satu sisi batik mengalami perkembangan pesat namun di sisi lain keunggulan batik melalui nilai-nilai yang terkandungnya perlahan tapi pasti semakin tenggelam. Hal ini terjadi karena masyarakat yang menggunakan batik tidak lagi berdasar pada nilai filosofi yang terkandung pada setiap motif, akan tetapi hanya terbatas pada kebutuhan pragmatis pengguna.

Pergeseran cara berpikir masyarakat tersebut distimulasi oleh fenomena komersialisasi pada kesenian batik. Artinya batik dipandang oleh masyarakat hanya sebatas kebutuhan untuk berpakaian dalam konteks tertentu saja. Dengan demikian makna kehidupan yang terkandung dalam setiap motif batik menjadi tidak lagi memiliki arti penting di mata masyarakat pengguna batik. Walaupun nilai-nilai yang terkandung dalam setiap motif batik tetap lestari, tetapi sudah tidak lagi diimplementasikan di dalam kehidupan keseharian oleh masyarakat. 
Fenomena munculnya berbagai metode baru dalam membatik, seperti kemunculan batik cap serta batik printing secara langsung atau pun tidak turut mempercepat terjadinya pergeseran nilai guna dalam kesenian batik itu sendiri. Jika pada masa lalu proses membatik membutuhkan waktu yang sangat panjang karena beragam tahapan yang harus dilalui tanpa menghilangkan nilai-nilai filosofis aslinya, dalam perkembangannya, proses tersebut dianggap oleh masyarakat tidak lagi menguntungkan dari sisi waktu dan kuantitas yang dihasilkan.

Di samping itu, pergeseran makna motif batik juga disebabkan oleh faktor-faktor lain, yakni:

1. Telah ada penerimaan di masyarakat bahwa batik merupakan produk budaya asli Indonesia sehingga berimplikasi pada kebutuhan yang semakin tinggi terhadap produk batik.

2. Batik diidentikkan dengan nasionalisme terhadap bangsa dan negara.

3. Faktor ekonomi Indonesia yang semakin berkembang ke arah kemajuan sehingga memunculkan kaum pengusaha dan wirausaha atau para pebisnis.

4. Batik menjadi komoditas ekspor sebagai penghasil devisa negara.

5. Degradasi lingkungan.

6. Kemajuan ilmu pengetahuan dan teknologi.

Setidaknya keenam faktor tersebut dalam pandangan peneliti sebagai penyebab terjadinya pergeseran makna pada motif batik Yogyakarta-Surakarta. Dimana nilai guna sesungguhnya dari sebuah karya seni batik telah beralih atau bergeser menjadi nilai jual dalam artian faktor ekonomi dan komersialisasi menjadi yang paling utama.

\section{Kesimpulan}

1. Pergeseran pada batik YogyakartaSurakarta dapat dilihat dari sisi proses pembuatan, bahan baku, teknologi (alat pembuatan batik), sehingga memengaruhi warna, motif, isen-isen dan makna yang terdapat dalam motif batik tersebut.
2. Pada zaman dulu, batik dibuat sesuai dengan nilai - nilai yang dianut oleh masyarakat, sehingga motif batik zaman dulu memiliki makna - makna filosofis. Namun, saat ini proses pembuatan batik dengan menggunakan bantuan teknologi justru menghasilkan motif yang beragam mengikuti selera pasar, sehingga makna yang terdapat dalam motif batik tidak lagi bernilai filosofis.

3. Batik tradisional mengandung makna filosofis sesuai dengan motif yang dihasilkan atau dimunculkan. Batik kontemporer tidak lagi memiliki makna filosofis dikarenakan penekanannya lebih kepada orientasi bisnis.

4. Pergeseran pada unsur-unsur batik Yogyakarta-Surakarta tersebut lebih dipengaruhi oleh faktor ekonomi, perkembangan teknologi serta permintaan pasar.

5. Dampak dari terjadinya pergeseran makna pada motif batik Yogyakarta-Surakarta menyebabkan filosofi yang terkandung dalam setiap motif batik menjadi tidak lagi diimplementasikan oleh masyarakat. Walaupun filosofi tersebut tidak hilang.

6. Walaupun demikian terdapat sisi positif dari kemunculan batik kontemporer, yakni batik semakin dikenal secara luas di masyarakat. Selain itu batik juga tidak lagi identik dengan penguasa. Oleh karena itu batik semakin diproduksi secara massal.

7. Idealnya, ketika batik semakin berkembang luas, tetap harus diimbangi dengan pemahaman yang kuat terhadap filosofi yang terkandung pada setiap motif batik.

\section{Daftar Pustaka}

\section{Buku}

Barker, Chris. 2005. Cultural Studies (Teori dan Praktek). Yogyakarta: PT. Benteng Pustaka.

Ishwara, Helen, Yahya, Supriyanto, Moeis, Xenia. 2011. Batik Pesisir Pusaka Indonesia. Jakarta: KPG (Kepustakaan Populer Gramedia). 
Kusrianto, Adi. 2007. Pengantar Desain Visual. Yogyakarta: CV. Andi Offset (Penerbit Andi).

Morissan., Wardhani, Andy Corry., Hamid U, Farid. 2010. Teori Komunikasi Massa Media, Budaya, dan Masyarakat. Bogor: PT. Ghalia Indonesia

Narwoko, J. Dwi dan Bagong Suyanto. 2004. Sosiologi Teks Pengantar dan Terapan. Jakarta: Kencana Prenada Media Grup.

Sudjiman, Panuti. 1993. Serba-serbi Semiotika. Jakarta: PT Gramedia Pustaka Utama.

Sobur, Alex. 2006. Analisis Teks Media (Suatu Pengantar Untuk Analisis Wacana, Analisis Semiotik dan Analisis Framming). Bandung: PT. Remaja Rosdakarya.
West, Richard dan Lynn H. Turner. 2008. Pengantar Teori Komunikasi: Analisis dan Aplikasi. Jakarta: Salemba Humanika.

Wulandari, Ari. 2011. Batik Nusantara Makna Filosofis, Cara Pembuatan \& Industri Batik. Yogyakarta: Andi.

\section{Sumber Lain}

Wulandari, Fiki Trisnawati. 2011. Pergeseran Makna Budaya bekakak Gamping (Analisisi Semiotika Pergeseran Makna Budaya Bekakak Gamping, Kab. Sleman). Ilmu Komunikasi Fakultas Ilmu Sosial dan Ilmu Politik Universitas Pembangunan Nasional: Tesis Tidak Diterbitkan.

\section{Situs Internet}

www.solobatik.althost.net, diakses pada 20 Juli 2013 pukul 15.00 WIB 